\title{
ANALISIS KESELAMATAN TERMOHIDROLIK BULK SHIELDING REAKTOR
} KARTINI

\author{
Azizul Khakim \\ BAPETEN, Jl. Gadjah Mada No. 8 Jakarta 10120 \\ a.khakim@bapeten.go.id \\ Diterima editor: 10 Agustus 2015 \\ Direvisi editor: 2 September 2015 \\ Disetujui untuk publikasi: 7 September 2015
}

\begin{abstract}
ABSTRAK
ANALISIS KESELAMATAN TERMOHIDROLIK BULK SHIELDING REAKTOR KARTINI. Bulk shielding merupakan fasilitas yang terintegrasi dengan reaktor Kartini yang berfungsi sebagai penyimpanan sementara bahan bakar bekas. Fasilitas ini merupakan fasilitas yang termasuk dalam struktur, sistem dan komponen (SSK) yang penting bagi keselamatan. Salah satu fungsi keselamatan dari sistem penanganan dan penyimpanan bahan bakar adalah mencegah kecelakaan kekritisan yang tak terkendali dan membatasi naiknya temperatur bahan bakar. Analisis keselamatan paling kurang harus mencakup analisis keselamatan dari sisi neutronik dan termo hidrolik Bulk shielding. Analisis termo hidrolik ditujukan untuk memastikan perpindahan panas dan proses pendinginan bahan bakar bekas berjalan baik dan tidak terjadi akumulasi panas yang mengancam integritas bahan bakar. Code tervalidasi PARET/ANL digunakan untuk analisis pendinginan dengan mode konveksi alam. Hasil perhitungan menunjukkan bahwa mode pendinginan konvekasi alam cukup memadai dalam mendinginkan panas sisa tanpa mengakibatkan kenaikan temperatur bahan bakar yang signifikan.
\end{abstract}

Kata kunci: Bulk shielding, bahan bakar bekas, konveksi alam, PARET.

\section{ABSTRACT}

THERMAL HYDRAULIC SAFETY ANALYSIS OF BULK SHIELDING KARTINI REACTOR. Bulk shielding is an integrated facility to Kartini reactor which is used for temporary spent fuels storage. The facility is one of the structures, systems and components (SSCs) important to safety. Among the safety functions of fuel handling and storage are to prevent any uncontrolable criticality accidents and to limit the fuel temperature increase. Safety analyses should, at least, cover neutronic and thermal hydraulic calculations of the bulk shielding. Thermal hydraulic analyses were intended to ensure that heat removal and the process of the spent fuels cooling takes place adequately and no heat accumulation that challenges the fuel integrity. Validated code, PARET/ANL was used for analysing the spent fuels cooling with natural convection mode. The calculations results concluded that natural convection cooling mode can adequately cools down the decay heat without significant increase in fuel temperatur.

Keywords: bulk shielding, spent fuels, natural convection, PARET. 


\section{PENDAHULUAN}

Bulk shielding merupakan fasilitas yang terintegrasi dengan reaktor Kartini yang berfungsi sebagai fasilitas penyimpanan sementara bahan bakar bekas. Fasilitas ini, menurut Peraturan Kepala BAPETEN No.1/2011 merupakan fasilitas yang termasuk dalam struktur, sistem dan komponen (SSK) yang penting bagi keselamatan [1]. Fasilitas lain yang termasuk dalam SSK yang penting bagi keselamatan adalah gedung dan struktur, teras reaktor, matriks dan kelongsong bahan bakar, sistem kendali reaktivitas (termasuk sistem pemadaman reaktor), untai pendingin primer, sistem pendingin darurat, sistem ventilasi, sistem proteksi reaktor, instrumentasi dan kendali yang berkaitan dengan keselamatan, catu daya listrik, pemantauan radiasi dan proteksi kebakaran.

Fungsi keselamatan dari sistem penanganan dan penyimpanan bahan bakar adalah memperkecil paparan radiasi, mencegah kecelakaan kekritisan yang tak terkendali, membatasi naiknya temperatur bahan bakar, menyimpan bahan bakar segar / teriradiasi, dan mencegah kerusakan mekanis atau kerusakan akibat korosi [1].

Karena Bulk shielding merupakan SSK yang penting bagi keselamatan, maka modifikasi terhadap Bulk shielding perlu diawali dengan kajian mendalam dari sisi keselamatan neutronik, termo hidrolik, maupun seismik. Analisis mandiri juga perlu dilakukan oleh BAPETEN sebagai badan pengawas untuk mendukung proses perijinan. Dalam perhitungan neutronik difokuskan pada perhitungan kritikalitas untuk memastikan kecelakaan kekritisan tidak akan terjadi dalam kondisi apa pun. Sedangkan analisis termo hidrolik ditujukan untuk memastikan perpindahan panas dan proses pendinginan bahan bakar bekas di dalam Bulk shielding berjalan baik dan tidak terjadi akumulasi panas.

Dalam makalah ini, analisis termo hidrolik pada mode konveksi alam di Bulk shielding dihitung dengan program PARET/ANL [2]. Code ini telah dibandingkan dengan eksperimen SPERT-I dan SPERT-II untuk sistem air ringan dan air berat [3]. Di samping itu PARET/ANL juga dibandingkan dengan RELAP5/MOD3 terhadap 10 MW IAEA Research Reactor [4] untuk empat kasus transien, yaitu transien LOF (Loss of Flow) cepat, transien LOF lambat, transien penyisipan reaktivitas lambat dan transien penyisipan reaktivitas cepat $[4,14]$. Secara keseluruhan kesesuaian antara PARET/ANL dan RELAP Code untuk serangkaian benchmark tersebut sangat baik, dan hasilnya sesuai dengan hasil guidebook. PARET/ANL juga telah dibenchmark dengan eksperimen reaktor TRIGA TAMU (Texas A\&M University) untuk kondisi pemulsaan dengan bahan bakar silinder FLIP (Fuel Lifetime Improvement Program) [5]. Y. Boulaich et.al menggunakan PARET untuk perhitungan kondisi tunak pada reaktor TRIGA MARK II dan membandingkannya dengan COOLOD-N2 [7]. A. Khakim et al menghitung perpindahan panas mode konveksi alam reaktor tipe MTR dengan PARET dan CONVEC [8].

\section{CODE PARET/ANL}

PARET (Program for the Analysis of Reactor Transient) digunakan untuk menganalisis reaktor uji dan reaktor riset. Analisis didasarkan pada evaluasi terkopel efek termal, hidrodinamik dan nuklir dalam teras. Teras model PARET/ANL berpendingin air dapat diwakili maksimum 4 elemen bahan bakar dan kanal pendinginnya. Jadi teras dapat dibagi maksimum 4 daerah, yang masing-masing mempunyai pembangkitan daya, laju aliran massa pendingin, parameter hidrolik yang berbeda, dan diwakili oleh pelat atau pin bahan bakar tunggal dengan kanal pendinginnya. Persoalan transien dispesifikasi secara eksternal melalui sisipan reaktivitas atau daya versus waktu. Program ini menghitung detail perpindahan panas, reaktivitas feedback yang kontinyu dan hidrodinamik yang memungkinkan aliran balik pendingin.

PARET/ANL bekerja pada korelasi perpindahan panas konveksi empiris pada antarmuka kelongsong-pendingin, baik konveksi alam atau paksa, pendidihan inti, transisi atau film stabil. Input Code meliputi: geometri dan dimensi fisik reaktor, parameter aliran fluida seperti koefisien drop tekanan, tekanan awal sistem, sifat termal material bahan bakar dan koefisien ekspansi termal kelongsong fungsi suhu, drop tekanan kanal, atau laju aliran massa masukan kanal fungsi waktu, entalpi moderator masukan, parameter pendidihan, informasi neutron kasip, rasio fluks neutron titik 
terhadap rerata, koefisien reaktivitas, daya awal, sisipan reaktivitas eksternal atau daya teras fungsi waktu.

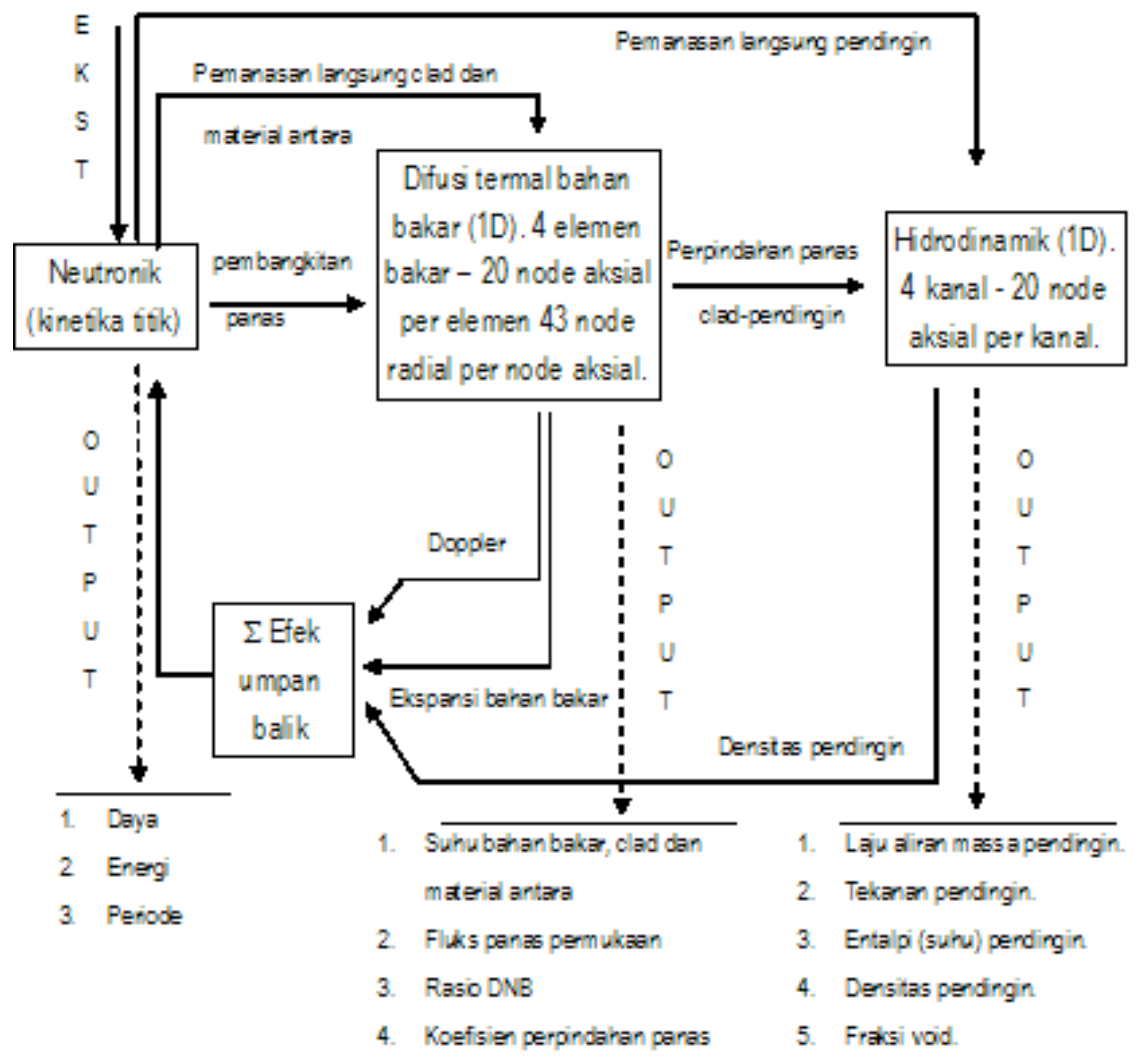

Gambar 1. Blok diagram model PARET

Keluaran perhitungan meliputi: mesh waktu, daya teras dan total energi yang dibangkitkan selama transien, reaktivitas tiap step dan reaktivitas feedback. Pada tiap titik aksial meliputi suhu moderator, kecepatan massa, fraksi void, suhu pusat dan permukaan bahan bakar, dan suhu permukaan kelongsong, fluks panas permukaan, rasio burnout, tekanan lokal, total drop tekanan sepanjang kanal. Hasil printout keluar setiap ke- $N$ node waktu, dimana $N$ dipilih oleh pengguna. Gambar 1 menunjukkan blok diagram model perhitungan dalam program PARET.

\section{Kinetika Reaktor}

Daya reaktor dihitung, baik dispesifikasi terhadap waktu atau ditentukan melalui penyelesaian numeris dari persamaan kinetika reaktor titik:

$$
\begin{aligned}
& \frac{\mathrm{d} \Phi(\mathrm{t})}{\mathrm{dt}}=\frac{[\rho(t)-\beta]}{\Lambda} \Phi(t)+\sum_{i=1}^{I} \lambda_{i} C_{i}(t)+S(t) \\
& \quad \frac{d C_{i}(t)}{d t}=\frac{\beta f_{i}}{\Lambda} \Phi(t)-\lambda_{i} C_{i}(t) \quad ; \quad i=1,2, . ., I
\end{aligned}
$$

dimana: $\quad t:$ waktu

$\Phi$ : daya reaktor

$\rho$ : reaktivitas sistem

$\beta$ : fraksi neutron kasip efektif

$\Lambda$ : waktu pembangkitan neutron serempak

$\lambda_{i}$ : konstanta peluruhan untuk grup $i$

$C_{i}$ : konsentrasi prekursor neutron kasip

$f_{i}$ : fraksi neutron kasip grup $i, \beta_{i} / \beta$ 
Karena dalam Bulk shielding tidak ada perubahan reaktivitas, maka persamaan (1) dan (2) tidak teraplikasi dalam persoalan ini.

\section{Persamaan Difusi Termal}

Perpindahan kalor dalam bahan bakar ditentukan dari penyelesaian konduksi $1-D$ hingga maksimum 20 daerah aksial (21 titik aksial). Tiap daerah aksial dibagi lagi maksimum 43 daerah radial (44 titik radial). Moderator dalam daerah aksial tidak dibagi secara radial, tapi cukup diwakili suhu bulk dan sifat fluida rata-rata. Tiap elemen bahan bakar dimungkinkan maksimum tiga daerah (bahan bakar, isolasi atau gap dan kelongsong).

Persamaan diferensial parsial untuk difusi kalor dalam bahan bakar:

$$
\frac{\partial}{\partial t}[g(u, r) u(r, t)]=\nabla \cdot k(u, r) \nabla u(r, t)+S(r, t)
$$

$u(r, t)$ adalah suhu sebagai fungsi posisi radial $r$ dan waktu $t$. Kapasitas panas volumetrik dan konduktivitas termal dinyatakan dengan $g(u, r)$ dan $k(u, r)$ sebagai fungsi suhu dan posisi. Sumber panas volumetrik, $S(r, t)$ diasumsikan fungsi terpisah dari ruang dan waktu. Besar sumber panas lokal ini ditentukan dari tingkat daya teras rata-rata terhitung atau terspesifikasi dan faktor bobot aksial dan radial yang diberikan. PARET/ANL menggunakan korelasi empiris perpindahan panas konveksi pada antarmuka pendingin dan kelongsong.

\section{Hidrodinamik}

Perhitungan hidrodinamik dalam PARET/ANL didasarkan pada model integral momentum termodifikasi yang mencakup hukum kekekalan massa, momentum, dan energi diselesaikan tiap kanal moderator tiap node waktu. Ketiga hukum tersebut diekspresikan oleh persamaan:

$$
\begin{gathered}
\frac{\partial \bar{\rho}}{\partial t}=-\frac{\partial G}{\partial z} \\
\frac{\partial G}{\partial t}+\frac{\partial}{\partial z}\left(\frac{G^{2}}{\rho^{\prime}}\right)=-\left(\frac{\partial p}{\partial z}\right)-\frac{f v|G| G}{2 D e}-\bar{\rho} g \\
\rho^{\prime \prime}\left(\frac{\partial H}{\partial t}\right)+G\left(\frac{\partial H}{\partial z}\right)=\frac{q}{r_{h}}
\end{gathered}
$$

dimana:

$z \quad=$ variabel jarak aksial

$\bar{\rho} \quad=$ densitas pendingin dua fasa terbobot volume

$G \quad=$ laju aliran massa pendingin

$\rho^{\prime} \quad=$ densitas efektif pendingin

$p, f=$ tekanan dan faktor gesekan

$v \quad=$ volume spesifik pendingin

$D_{e} \quad=$ diameter ekuivalen kanal pendingin

$g \quad=$ konstanta gravitasi

$\rho^{\prime \prime} \quad=$ densitas aliran slip efektif dari pendingin

$H \quad=$ entalpi pendingin

$r_{h} \quad=$ jari-jari hidrolik kanal pendingin

$q \quad=$ energi termal yang diperoleh pendingin

Penyelesaian persamaan (4), (5) dan (6) menghasilkan drop tekanan sepanjang teras, tekanan per titik, entalpi fluida, dan laju aliran massa sepanjang tiap kanal. Variasi kecepatan dan sifat-sifat fluida dianggap 1-D pada arah aliran. Deskripsi ini memungkinkan aliran balik pendingin, dan kondisi fisik pendingin mencakup subdingin (subcooled) hingga daerah dua fasa termasuk uap panas lanjut (superheated). 


\section{MODEL PERHITUNGAN BULK SHIELDING}

Bulk shielding reaktor Kartini berbentuk kotak dengan ukuran panjang 2,29 m lebar 1,12 m dan kedalaman 3,8 m. Material dinding Bulk shielding berupa aluminium dengan ketebalan $6 \mathrm{~mm}$, sedangkan kerangkanya terbuat dari besi. Level air permukaan rata-rata $15 \mathrm{~cm}$ di bawah bibir tangki.

Bahan bakar tipe 104 memiliki panjang total $75 \mathrm{~cm}$ dengan panjang aktif $38 \mathrm{~cm}$. Di ujung atas dan di ujung bawah batang bahan bakar diletakkan grafit sepanjang masing-masing $6,6 \mathrm{~cm}$ dan $9,39 \mathrm{~cm}$ yang berfungsi sebagai reflektor aksial. Di antara ujung bawah batang bahan bakar dan grafit disisipkan racun dapat bakar yang berupa cakram Mo dengan tebal $0,127 \mathrm{~cm}$ dan berdensitas $10,2 \mathrm{~g} / \mathrm{cm}^{3}$. Material kelongsong bahan bakar berupa SS-304 dengan diameter luar $3,7 \mathrm{~cm}$ dan tebal $0,05 \mathrm{~cm}$. Material bahan bakar terbuat dari UZrH dengan diameter luar 3,56 $\mathrm{cm}$ dan berdensitas $5,64 \mathrm{~g} / \mathrm{cm}^{3}$. Berat kandungan U-235 dalam UZrH rata-rata adalah $38 \mathrm{~g}$. Di antara bahan bakar dan kelongsong terdapat gap setebal $0,02 \mathrm{~cm}[6,12]$.

Gambar 2 menggambarkan deskripsi rak penyimpanan bahan bakar bekas dan dimensinya. Reaktor Kartini memiliki tiga buah rak penyimpanan bahan bakar bekas dengan ukuran panjang $106,5 \mathrm{~cm}$ lebar $31,5 \mathrm{~cm}$ dan tinggi $70 \mathrm{~cm}$. Rak tersebut dapat memuat 30 batang bahan bakar. Bulk shielding dapat dimuati 6 buah rak yang disusun secara mendatar. Saat ini terdapat 76 bahan bakar teriradiasi dan satu bahan bakar segar, sehingga total ada 77 batang bahan bakar.

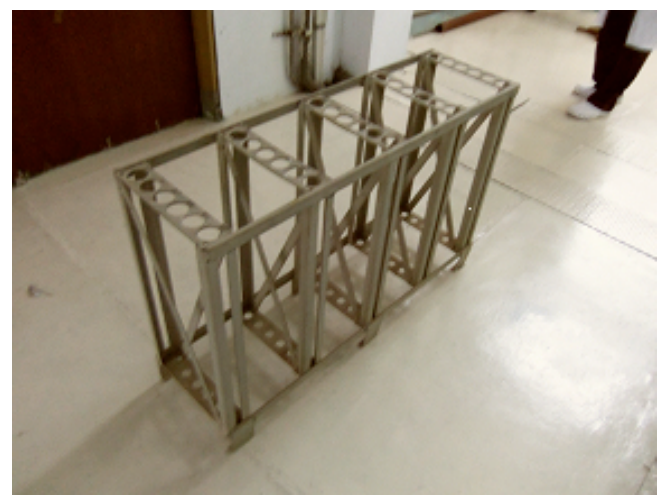

(a)

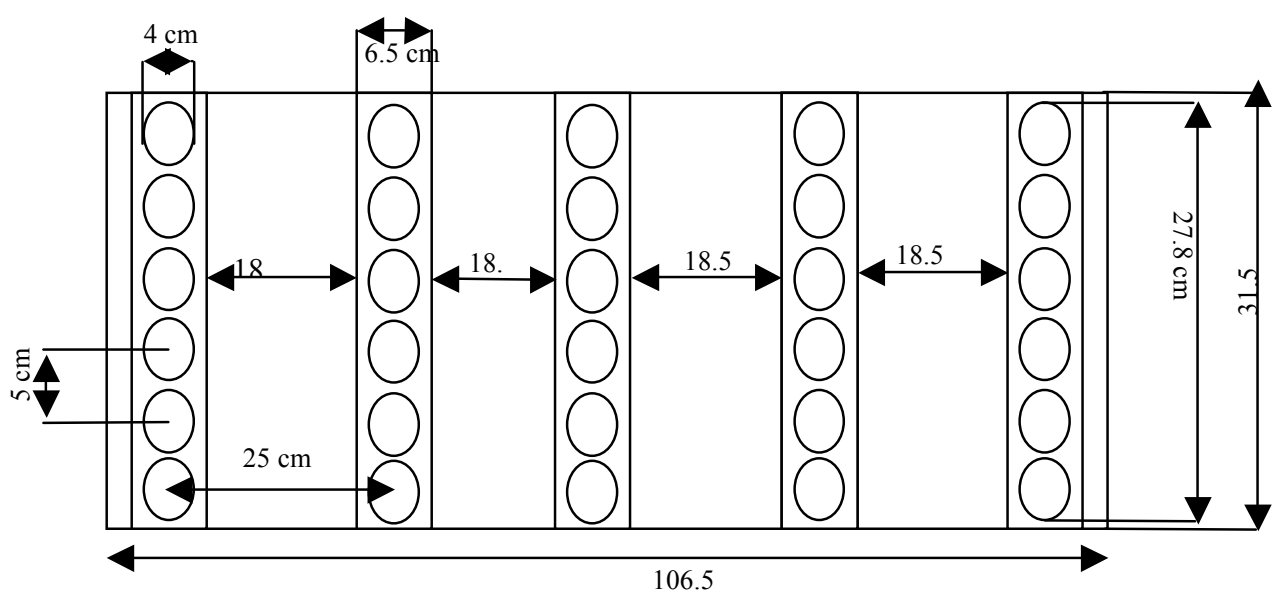

(b)

Gambar 2. (a) Foto rak dan (b) Dimensi rak penyimpanan bahan bakar bekas

Bulk shielding reaktor Kartini dirancang untuk didinginkan dengan mode konveksi alam. Analisis dilakukan dengan Code PARET/ANL dengan mode pendinginan sirkulasi alam. Jumlah pin bahan bakar dalam Bulk shielding diasumsikan penuh 90 buah dengan konfigurasi rak mendatar. 
Dengan mengambil pendekatan konservatif, daya pin bahan bakar bekas diasumsikan 5\% dari daya nominal pin reaktor Kartini atau 72,5 W. Pada prakteknya bahan bakar bekas dipindahkan dari teras ke Bulk shielding dengan daya sisa yang jauh lebih kecil dari $5 \%$ daya nominal. Nilai tersebut diperoleh dari kenyataan bahwa teras reaktor Kartini tersusun dari 69 batang bahan bakar dan beroperasi pada daya nominal $100 \mathrm{~kW}$. Daya 5\% dari daya nominal sebenarnya tercapai hanya beberapa detik setelah reaktor shutdown, sebagaimana terlihat pada Gambar 3. Namun pada kenyataannya bahan bakar bekas akan dipindahkan ke bulk shielding setelah beberapa hari (bahkan bulan) setelah shutdown. Dari Gambar 3 terlihat bahwa daya 5\% dari daya nominal tercapai pada detik ke-8 (menurut model Todreas [10]) dan detik ke-20 (menurut model RETRAN [11]). Pendekatan lain yang membuat hasil perhitungan ini konservatif adalah faktor puncak daya aksial dan radial yang masing-masing sebesar 1,26 dan 1,7.

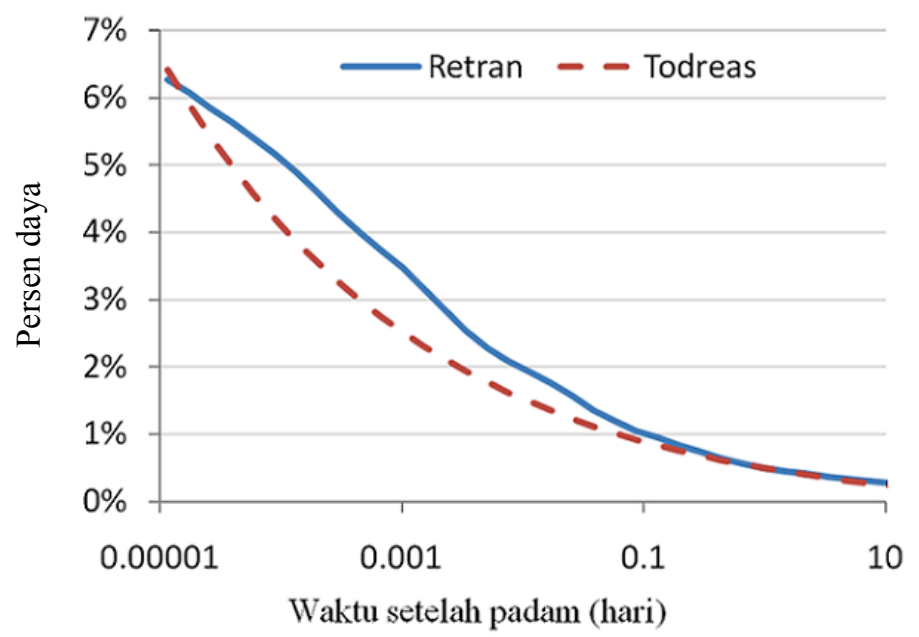

Gambar 3. Profil penurunan daya panas sisa model RETRAN dan Todreas [11].

Karena Code PARET/ANL mensyaratkan jarak pin seragam dengan sekelilingnya maka, penyederhanaan konfigurasi pin dilakukan dari $25 \mathrm{~cm}$ x $5 \mathrm{~cm}$ menjadi $5 \mathrm{~cm} \times 5 \mathrm{~cm}$. Hal ini membuat hasil perhitungan menjadi lebih konservatif, karena kanal pendingin menjadi lebih sempit. Dengan mengacu pada Gambar 2.(B), maka luas kanal pendingin dihitung dengan persamaan:

$$
A_{C H N}=p l-\frac{1}{4} \pi D^{2}
$$

di mana $p=l=5 \mathrm{~cm} . D$ adalah diameter pin bahan bakar. Sedangkan, wetted perimeter dihitung dengan:

$$
P_{w}=\pi D
$$

Hidrolik diameter didefinisikan sebagai:

$$
D_{h}=\frac{4 A_{C H N}}{P_{w}}
$$


Tabel 1. Data perhitungan termo hidrolik Bulk shielding

\begin{tabular}{llc}
\hline No. & Parameter & Nilai \\
\hline 1. & Mode pendinginan & konveksi alam \\
2. & Konfigurasi pin & square $5 \mathrm{~cm} \times 5 \mathrm{~cm}$ \\
3. & Daya per pin, \% nominal & 5,0 \\
4. & Temperatur bulk kolam, ${ }^{\circ} \mathrm{C}$ & 32,2 \\
5. & Jumlah node arah aksial & 21 \\
6. & Jumlah node arah radial & 19 \\
7. & Faktor puncak daya aksial (FA) & 1,26 \\
8. & Faktor puncak daya radial (FR) & 1,70 \\
9. & Konduktivitas panas UZrH, w/m ${ }^{\circ} \mathrm{C}$ & 18,0 \\
10. & Fuel-clad gap conductance, $\mathrm{W} / \mathrm{cm}^{2} \cdot{ }^{\circ} \mathrm{C}$ & 1,0 \\
11. & Konduktivitas panas kelongsong, $\mathrm{w} / \mathrm{m}{ }^{\circ} \mathrm{C}$ & 227,0 \\
12. & Jumlah bahan bakar & 90 \\
13. & Luas area satu kanal pendingin, $\mathrm{cm}^{2}$ & 14,25 \\
14. & Diameter hidrolik, cm & 4,9 \\
\hline
\end{tabular}

Bilangan Reynolds:

$$
\operatorname{Re}=\frac{\rho V D_{h}}{\mu}
$$

Kapasitas panas material $\mathrm{UZrH}_{1.6}\left(\right.$ dalam $\mathrm{J} / \mathrm{m}^{3 \circ} \mathrm{C}$ ) dinyatakan sebagai fungsi temperatur:

$$
C_{P}=2,04 \times 10^{6}+4,17 \times 10^{3} T
$$

Data-data lain yang diperlukan untuk penyusunan input tertera pada Tabel 1. Dalam perhitungan ini daya diasumsikan konstan selama waktu transien dan tidak ada reaktivitas feedback [13]. Sehingga dalam PARET/ANL digunakan mode "power level specified", karenanya persamaan kinetika reaktor (point kinetic) tidak diselesaikan dalam perhitungan [15].

\section{Strategi Perhitungan}

Code PARET/ANL tidak menyediakan mode pendinginan konveksi alam secara langsung, karena pada $t=0$ temperatur pendingin seragam di semua node (mesh), yaitu sama dengan temperatur tebakan awal, sehingga tidak ada buoyancy yang tercipta. Karena tidak ada buoyancy dan tidak ada tekanan paksa dari pompa, maka persamaan (5) tidak bisa diselesaikan. Namun dari persamaan (5) terdapat suku $(\rho g)$ yang memungkinkan terjadinya aliran sirkulasi alam ke atas setelah shutdown dan hilangnya aliran pompa. Sehingga perlu strategi untuk mensimulasikan perhitungan kondisi tunak dengan mode konveksi alam dalam PARET/ANL, yaitu sebagai berikut $[8,9]$ :

1. memberi aliran paksa ke atas atau ke bawah sebagai inisiasi. Aliran ini sebagai driving force $(\partial p / \partial z)$ dari persamaan (5) pada $t=0$, sehingga persamaan tersebut dapat diselesaikan. Dengan demikian, di time step berikutnya buoyancy sudah tercipta. Ketika buoyancy sudah tercipta, maka aliran paksa bisa dihilangkan.

2. menghilangkan aliran paksa dengan memanfaatkan card coast down pump. Mematikan aliran paksa ini berarti menghilangkan suku $(\partial p / \partial z)$ dari persamaan (5), sehingga driving force yang tersisa adalah suku $(\rho g)$ yang membawa aliran ke atas sebagai gaya buoyancy.

3. menonaktifkan low flow trip point. Code PARET/ANL menyediakan sinyal trip dari penurunan laju alir (low flow trip point), yang berfungsi untuk melakukan tindakan scram jika laju alir berkurang di bawah level tertentu. Menonaktifkan low flow trip point dengan memberi nilai 0,0 pada card ini, bertujuan agar langkah ke-2 tidak menyebabkan reaktor scram.

4. Perhitungan dilakukan dengan mode transien. Memasukan waktu transien yang cukup panjang untuk memastikan konveksi alam telah berjalan stabil. menganalisis semua parameter untuk memastikan bahwa semua nilai tersebut sudah stabil atau konstan. Kondisi konstan atau stabil inilah yang merupakan pendinginan konveksi alam Bulk shielding kondisi tunak. 
Analisis sensitivitas terhadap laju alir awal (inisiasi) perlu dilakukan untuk menunjukkan bahwa besarnya laju alir sirkulasi alam tidak tergantung besarnya laju alir awal, tetapi tergantung daya pin bahan bakar.

\section{HASIL DAN PEMBAHASAN}

Berbagai laju rapat massa awal yang berbeda akan menghasilkan laju rapat massa sirkulasi alam yang sama untuk daya tertentu. Dengan demikian, laju alir sirkulasi alam tidak tergantung berapa pun laju alir inisiasi yang diberikan pada input data. Rapat massa awal sebesar $5 \mathrm{~kg} / \mathrm{m}^{2} \mathrm{~s}, 25$ $\mathrm{kg} / \mathrm{m}^{2} \mathrm{~s}$, dan $100 \mathrm{~kg} / \mathrm{m}^{2} \mathrm{~s}$ disimulasikan untuk daya pin 5,0\% dari daya nominal. Gambar 4 menunjukkan perilaku transien aliran pada berbagai rapat massa inisiasi. Transien disimulasikan hingga 400 detik, dan kondisi stabil (tunak) tercapai kira-kira pada detik ke-250, di mana rapat masa (laju alir) mencapai harga yang sama untuk ketiga laju alir inisiasi. Pada kondisi stabil, rapat massa pendingin mencapai $17,74 \mathrm{~kg} / \mathrm{m}^{2} \mathrm{~s}$.

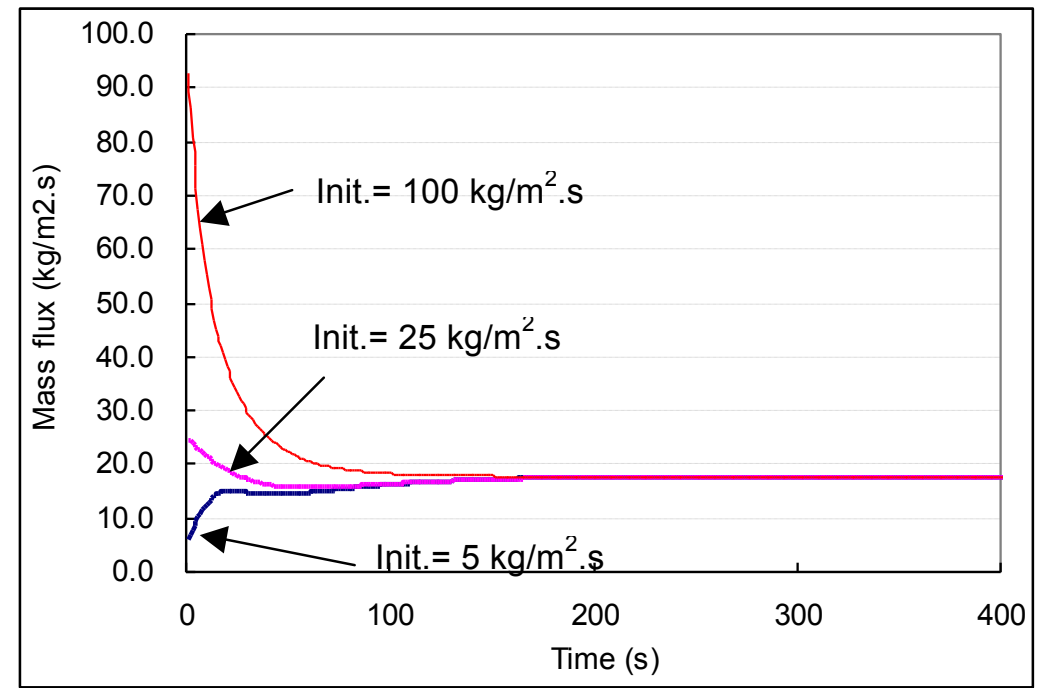

Gambar 4. Perilaku transien aliran pada berbagai rapat massa inisiasi

Gambar 5 menunjukkan perilaku transien temperatur pusat bahan bakar pada berbagai rapat massa awal. Pada detik ke-250 tercapai kondisi stabil temperatur pusat bahan bakar pada mode pendinginan konveksi alam sebesar $38,6{ }^{\circ} \mathrm{C}$.

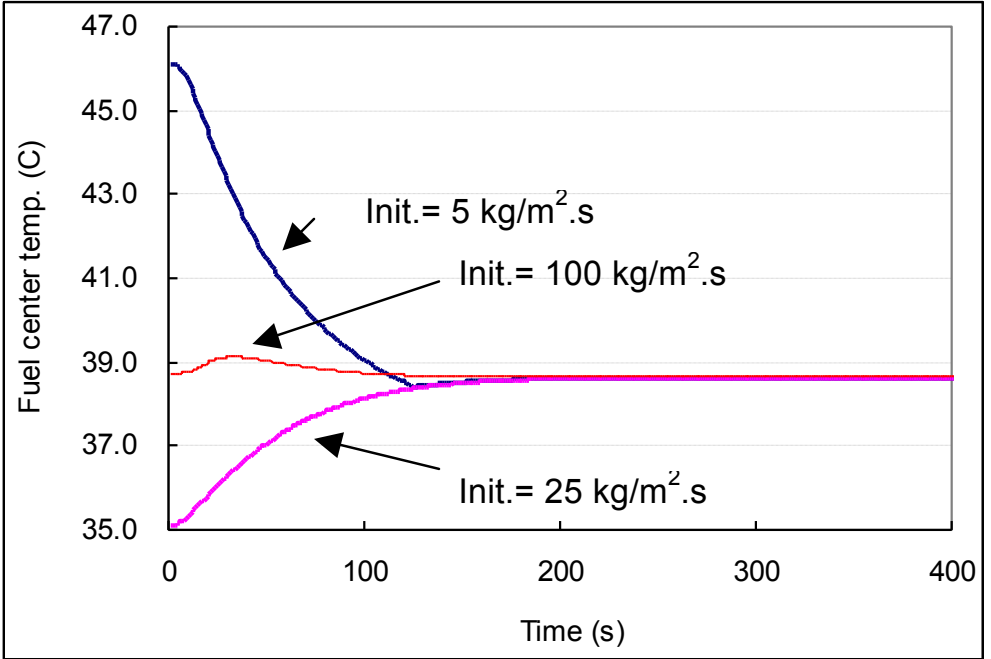

Gambar 5. Perilaku transien temperatur pusat bahan bakar pada berbagai harga inisiasi rapat massa 
Analisis sensitivitas juga dilakukan terhadap tiga profil penghilangan aliran paksa secara coastdown, sebagaimana terlihat pada Gambar 6 . Ketiga profil penghilangan aliran paksa secara coastdown diasumsikan memberikan waktu henti aliran masing-masing $15 \mathrm{~s}, 20 \mathrm{~s}$ dan $30 \mathrm{~s}$. Analisis sensitivitas ini ditujukan untuk mengetahui pengaruh kecepatan berhentinya aliran pompa terhadap besarnya laju alir sirkulasi alam setelah tercapai kondisi stabil.

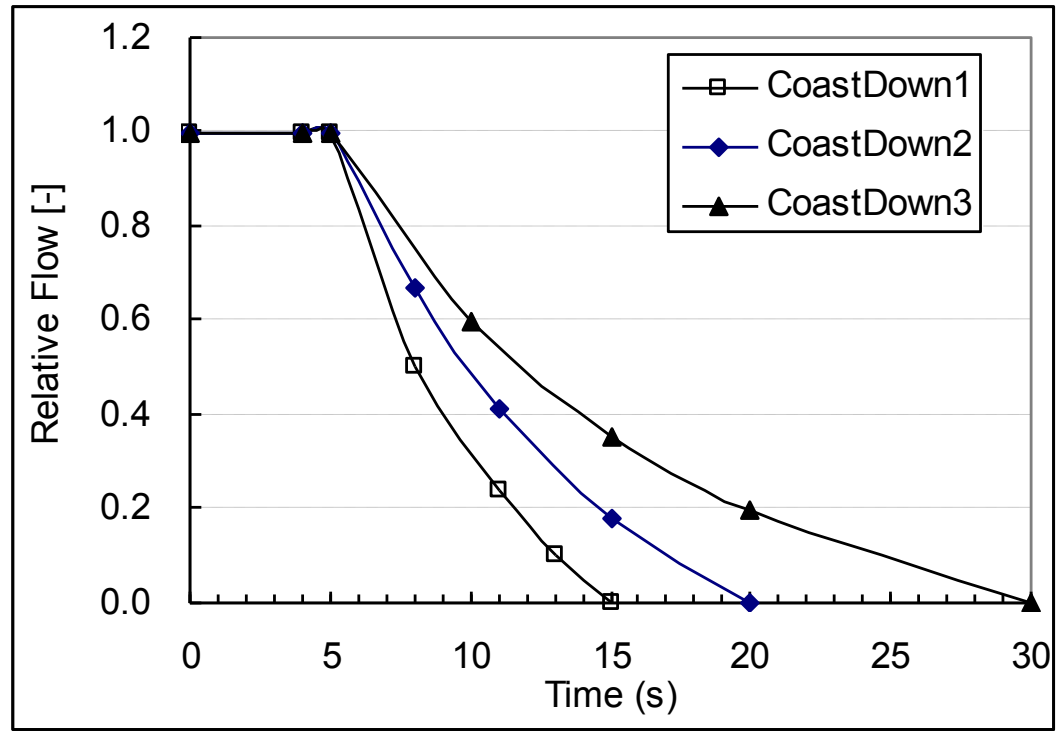

Gambar 6. Profil coastdown aliran pompa

Gambar 7 menunjukkan laju alir sirkulasi alam saat kondisi stabil yang disimulasikan dengan tiga profil aliran coastdown yang berbeda (Gambar 6) pada laju aliran inisiasi $100 \mathrm{~kg} / \mathrm{m}^{2} . \mathrm{s}$. Dari gambar tersebut terlihat bahwa besarnya laju alir sirkulasi alam sama untuk semua profil coastdown, yang berarti profil coastdown tidak berpengaruh terhadap besarnya laju alir sirkulasi alam. Dengan demikian, strategi perhitungan pendinginan sirkulasi alam dengan Code PARET/ANL cukup andal dengan batasan pendidihan masif belum terjadi.

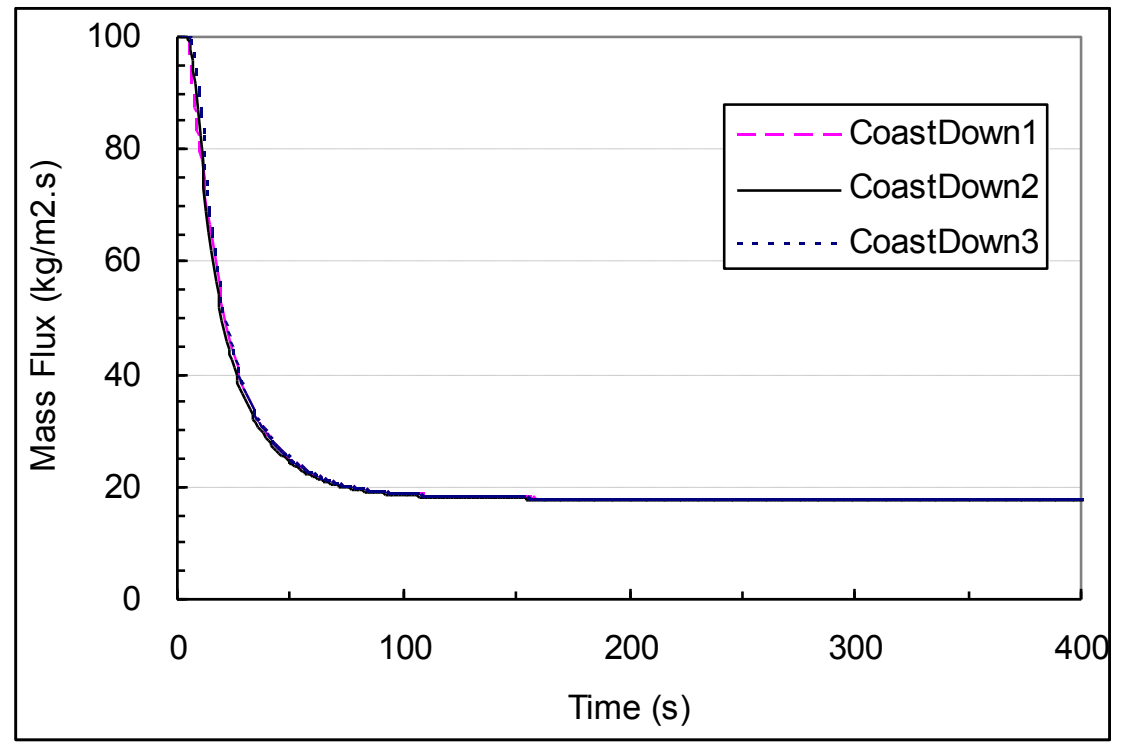

Gambar 7. Laju alir sirkulasi alam terhadap beberapa profil coastdown pompa

Tabel 2 menyajikan ringkasan hasil perhitungan bahan bakar bekas dalam Bulk shielding dengan mode pendinginan konveksi alam. Analisis ini memodelkan 90 batang bahan bakar yang disusun dalam tiga rak secara mendatar, di mana jarak antar rak adalah $0,0 \mathrm{~cm}$ (saling menempel). Dengan daya 5,0 \% dari daya nominal pin reaktor Kartini, membangkitkan fluks alir massa 
sirkulasi alam sebesar $17,74 \mathrm{~kg} / \mathrm{m}^{2}$.s. Kecepatan maksimum pendingin di kanal terpanas yang terletak di tengah konfigurasi adalah $1,78 \mathrm{~cm} / \mathrm{s}$, sedangkan temperatur maksimum pendingin di kanal tersebut adalah $32,60^{\circ} \mathrm{C}$. Pada tekanan lokal kanal, pendingin masih dalam regime liquid karena masih jauh di bawah temperatur dua fasa $113,60{ }^{\circ} \mathrm{C}$. Fluks panas maksimum permukaan batang bahan bakar mencapai $2026,0 \mathrm{w} / \mathrm{m}^{2}$. Temperatur maksimum di pusat bahan bakar adalah $38,64{ }^{\circ} \mathrm{C}$, jauh lebih kecil dari batas desain temperatur bahan bakar reaktor Kartini, yaitu $750{ }^{\circ} \mathrm{C}$.

Tabel 2. Hasil perhitungan konveksi alam bahan bakar dalam Bulk shielding

\begin{tabular}{clc}
\hline No. & Parameter & Harga \\
\hline 1. & Daya per pin, W & $71,43(5 \%)^{\mathrm{a}}$ \\
2. & Jumlah pin bahan bakar & 90 \\
3. & Flux massa aliran konveksi alam stabil, $\mathrm{kg} / \mathrm{m}^{2} . \mathrm{s}$ & 17,74 \\
4. & Kecepatan max. pendingin, cm $/ \mathrm{s}$ & 1,78 \\
5. & Temperatur max. pendingin, ${ }^{\circ} \mathrm{C}$ & 32,60 \\
6. & Temperatur max. kelongsong, ${ }^{\circ} \mathrm{C}$ & 36,94 \\
7. & Temperatur max. bahan bakar, ${ }^{\circ} \mathrm{C}$ & 38,64 \\
8. & Regime pendingin & Liquid \\
9. & Temperatur dua fasa, ${ }^{\circ} \mathrm{C}$ & 113,60 \\
10. & Temperatur DNB ${ }^{\mathrm{b}},{ }^{\circ} \mathrm{C}$ & 151,37 \\
11. & Fluks panas permukaan maksimum, $\mathrm{w} / \mathrm{m}^{2}$ & 2026,0 \\
\hline erhadap daya nominal reaktor Kartini &
\end{tabular}

Gambar 8 mendeskripsikan distribusi aksial temperatur pusat bahan bakar, kelongsong dan pendingin di kanal terpanas. Secara aksial temperatur terpanas dari bahan bakar dan kelongsong terletak di tengah (midplane), sedangkan temperatur pendingin maksimum berada pada outlet kanal pendingin.

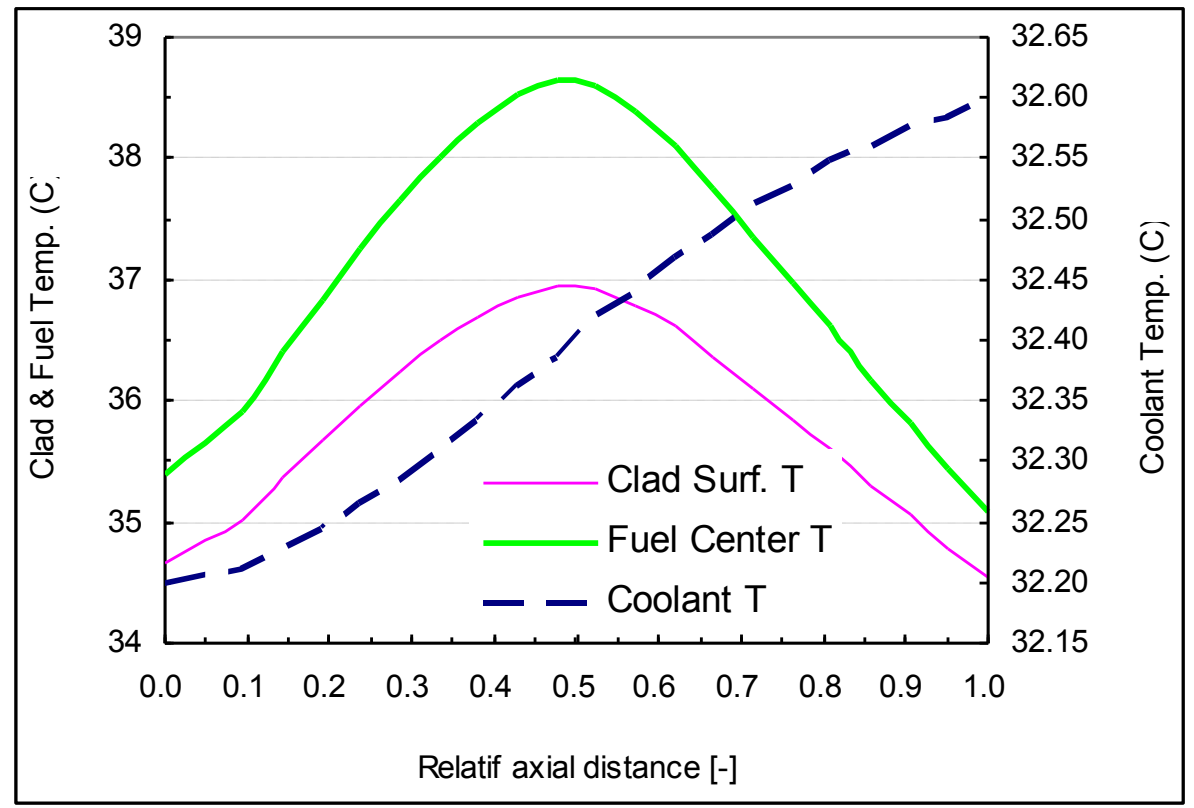

Gambar 8. Distribusi temperatur pusat bahan bakar, kelongsong dan pendingin

Sensitivity analisis juga dilakukan dan dibandingkan dengan kisi $5 \mathrm{~cm} \times 25 \mathrm{~cm}$. Analisis ini ditujukan untuk menunjukkan bahwa kisi $5 \mathrm{~cm} \times 5 \mathrm{~cm}$ lebih konservatif dari pada kisi rak yang sebenarnya $5 \mathrm{~cm} \times 25 \mathrm{~cm}$. Kisi $5 \mathrm{~cm} \times 25 \mathrm{~cm}$ disederhanakan seperti Gambar 9 dengan tetap mempertahankan hidrolik diameter $\left(D_{h}\right)$ konstan: 

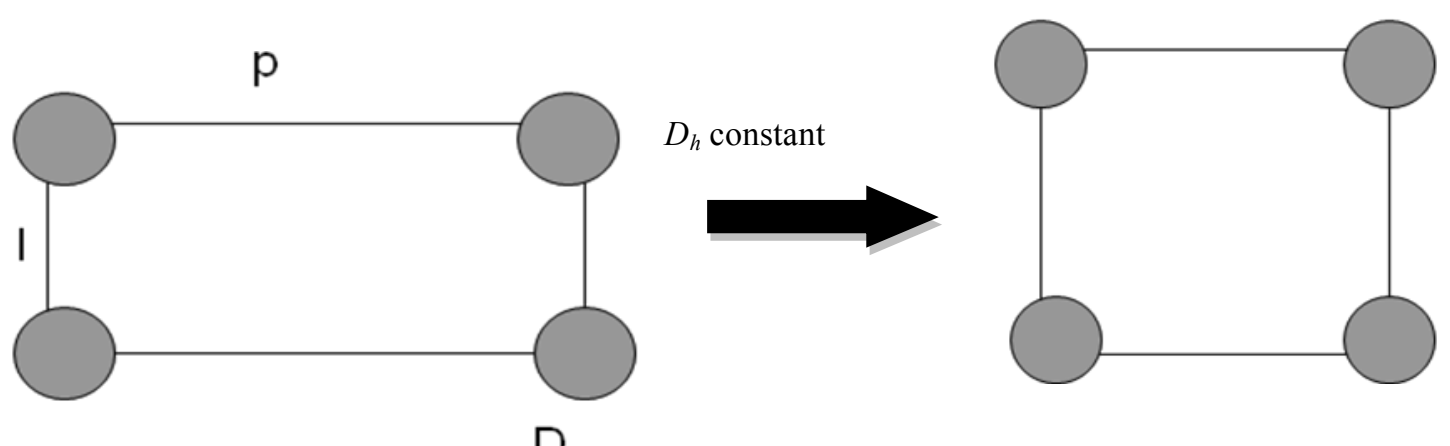

Gambar 9. Penyederhanaan kisi $5 \mathrm{~cm}$ x $25 \mathrm{~cm}$ dalam PARET/ANL

Kanal segi empat yang terbentuk memiliki luas $114,25 \mathrm{~cm}^{2}$ dan hidolik diameter $39,32 \mathrm{~cm}$. Dengan jumlah batang bahan bakar bekas sama dengan 90 dan rapat massa awal pendingin 5 $\mathrm{kg} / \mathrm{m}^{2} \mathrm{~s}$ diperoleh laju alir sirkulasi alam $10,3 \mathrm{~kg} / \mathrm{m}^{2} \mathrm{~s}$, lebih rendah dari kisi $5 \mathrm{~cm} \times 5 \mathrm{~cm}$, seperti yang terlihat pada Gambar 10 .

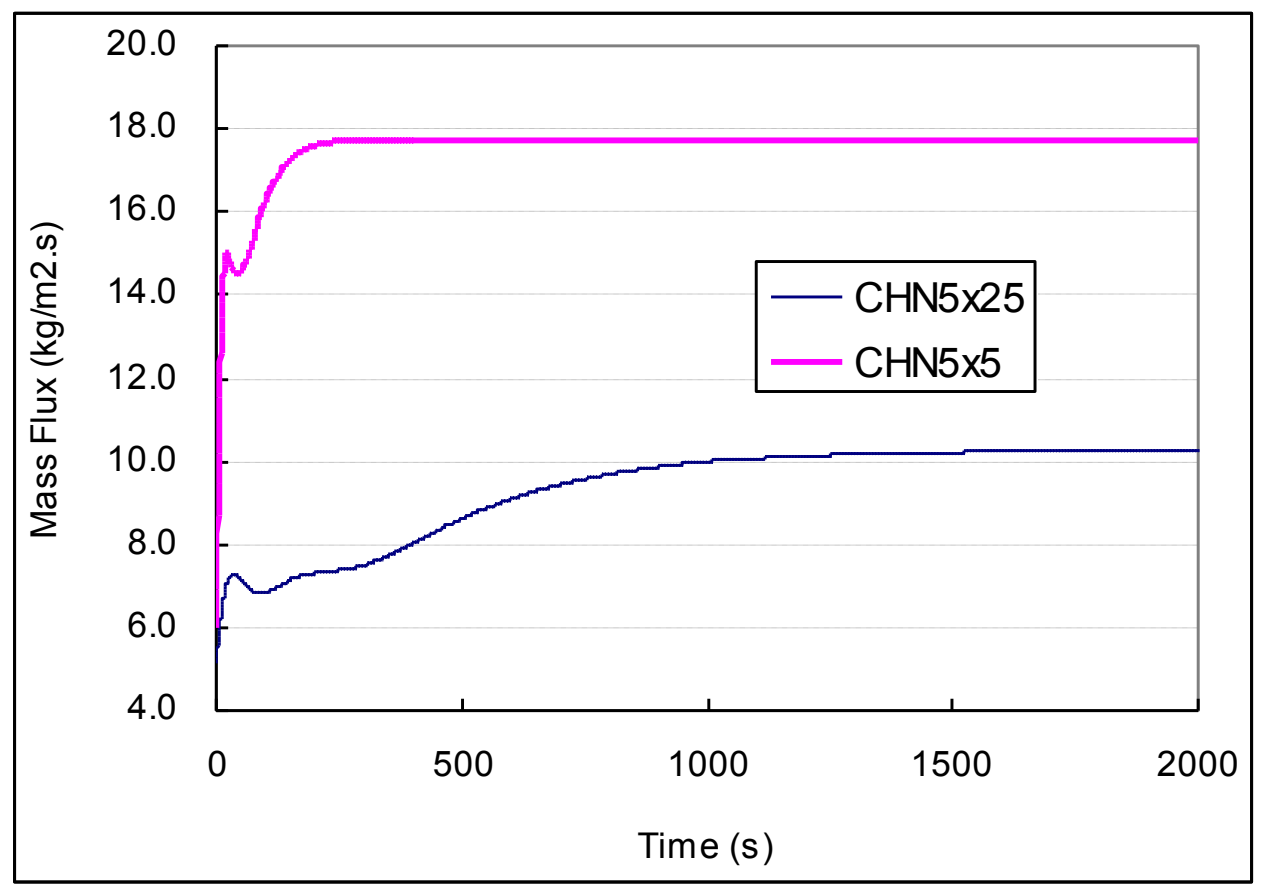

Gambar 10. Perbandingan rapat massa sirkulasi alam pada kisi $5 \mathrm{~cm}$ x $5 \mathrm{~cm}$ dan $5 \mathrm{~cm} \times 25 \mathrm{~cm}$

\section{KESIMPULAN}

Perhitungan kemampuan pendinginan konveksi alam Bulk shielding reaktor Kartini telah dilakukan dengan Code PARET/ANL dengan daya pin bahan bakar bekas 5,0 \% dari daya nominal. Hasil perhitungan menyimpulkan bahwa:

1. Temperatur maksimum bahan bakar $\left(38.64{ }^{\circ} \mathrm{C}\right)$ berada jauh di bawah batas desain temperatur bahan bakar untuk operasi normal $750{ }^{\circ} \mathrm{C}$.

2. Temperatur pendingin maksimum $32.6{ }^{\circ} \mathrm{C}$, jauh di bawah temperatur dua fasa $113.6{ }^{\circ} \mathrm{C}$. Seluruh pendingin berada pada regime liquid.

3. Dengan demikian, dari sisi temperatur bahan bakar dan pendingin Bulk shielding dapat dijaga dalam kondisi aman dengan margin yang cukup besar. 


\section{UCAPAN TERIMA KASIH}

Penulis mengucapkan terima kasih kepada Bapak Ir. Puradwi I.W (BATAN-Yogyakarta) yang telah memfasilitasi pengambilan data untuk analisis subkritikalitas dan analisis termo hidrolik Bulk shielding reaktor Kartini, sebagai bagian dari analisis mandiri yang dilakukan oleh Badan Pengawas.

\section{DAFTAR PUSTAKA}

1. BAPETEN, Ketentuan Keselamatan Desain Reaktor Nondaya (Lampiran II), Peraturan Kepala BAPETEN No. 1/ 2011, 2011.

2. Olson, A.P. A Users Guide to the PARET-ANL Code. 2012. Argonne National laboratory. ANL/RERTR/TM-11-38.

3. W.L. Woodruff. Additional Capabilities and Benchmarking with the SPERT Transient for Heavy Water Applications of the PARET Code. Proc. of International Meeting on Reduced Enrichment for Research and Test Reactors; 1989 September 10-14. Berlin, Germany; 1989. p.357-365.

4. W.L. Woodruff, N.A. Hanan, R.S. Smith and J.E. Matos. Comparison of the PARET/ANL and RELAP5/MOD3 Code for the Analysis of IAEA Benchmark Transients. International Meeting on Reduced Enrichment for Research and Test Reactors. 1996 October. Seoul.

5. Theodore A. Parish. Nuclear Safety Analyses and Core Design Calculations to Convert the Texas A\&M University Nuclear Science Center Reactor to Low Enrichment Uranium Fuel. 1995 March 2. Report.

6. PTAPB-BATAN, Laporan Analisis Keselamatan Reaktor Kartini, Rev.7, Februari 2007.

7. Y. Boulaich, B. Nacir, T. El Bardouni, M. Zoubair, B. El Bakkari, Q. Merroun, C. El Younoussi, A. Htet, H. Boukhal and E. Chakir, Steady-state Thermal-hydraulic Analysis of the Moroccan TRIGA MARK II Reactor by Using PARET/ANL and COOLOD-N2 Codes, Nuclear Engineering and Design 2011, 241: 270-273.

8. Azizul Khakim. Analisis Keselamatan Reaktor RSG GAS pada Moda Pendinginan Konveksi Alam, Prosiding Teknologi dan Keselamatan PLTN serta Fasilitas Nuklir ke-17 (TKPFN-17). 1 Oktober 2011. Yogyakarta.

9. Azizul Khakim. Analisis Termohidrolika Kehilangan Aliran Pendingin Reaktor RSG GAS dengan Bahan Bakar $\mathrm{U}_{3} \mathrm{Si}_{2}-\mathrm{Al}$. Prosiding Pertemuan dan Presentasi Ilmiah P3TM-BATAN. 25-26 Juli 2000. Yogyakarta.

10. Neil E. Todreas and Mujid S. Kazimi. Nuclear System I: Thermal Hydraulic Fundamentals. Hemisphere Publishing Corporation; 1990, ISBN 0-89116-935-0 (v.1).

11. ---, Available from: URL: http://en.wikipedia.org/wiki/File:Decay heat illustration.PNG. Accessed Agustus 20, 2015.

12. Azizul Khakim. Analisis Subkritikalitas Bulkshielding Reaktor Kartini. Prosiding Pertemuan dan Presentasi Ilmiah - Penelitian Dasar Ilmu Pengetahuan dan Teknologi Niklir PTAPBBATAN. 26 Juni 2013. Yogyakarta.

13. Mesquita, A.Z., et al. Thermal-hydraulic and neutronic experimental research in the TRIGA reactor of Brazil. Progress in Nuclear Energy 2014; 76:183-190.

14. Rahman, M.M., et al. Steady-State Thermal-Hydraulic Analysis of TRIGA Research Reactor. World Journal of Nuclear Science and Technology 2014; 4: 81-87.

15. Adoo, N.A., et al. Determination of the thermal hydraulic data of GHARR-1 under reactivity insertion transients using the PARET/ANL code. Nuclear Engineering and Design 2011; 241(12): 5203-5210. 